\title{
Optimization of Extraction Conditions for Total Phenolics and Total Flavonoids from Kaempferia parviflora Rhizomes
}

\author{
Zuraida Ab Rahman', Shazwan Abd Shukor1, Hartinee Abbas², Chandradevan A. L. Machap1, \\ Mohd Suhaimi Bin Alias³, Razali Mirad4, Syairah Sofiyanand5, Ayu Nazreena Othman1 \\ ${ }^{1}$ Biotechnology \& Nanotechnology Research Centre, MARDI HQ, Persiaran MARDI-UPM, Serdang, Malaysia \\ ${ }^{2}$ Horticulture Research Centre MARDI Sintok, Bukit Kayu Hitam, Malaysia \\ ${ }^{3}$ Food Technology Research Centre, MARDI HQ, Persiaran MARDI-UPM, Serdang, Malaysia \\ ${ }^{4}$ Agrobiodiversity and Environment Research Centre, MARDI HQ, Persiaran MARDI-UPM, Serdang, Malaysia \\ ${ }^{5}$ Nilai Polytechnic, Kompleks Pendidikan Bandar Enstek, Bandar Enstek, Malaysia \\ Email: azuraida@mardi.gov.my
}

How to cite this paper: Rahman, Z.A., Shukor, S.A., Abbas, H., Machap, C.A.L., Alias, M.S.B., Mirad, R., Sofiyanand, S. and Othman, A.N. (2018) Optimization of Extraction Conditions for Total Phenolics and Total Flavonoids from Kaempferia parviflora Rhizomes. Advances in Bioscience and Biotechnology, 9, 205-214. https://doi.org/10.4236/abb.2018.95014

Received: March 29, 2018

Accepted: May 15, 2018

Published: May 18, 2018

Copyright $\odot 2018$ by authors and Scientific Research Publishing Inc. This work is licensed under the Creative Commons Attribution International License (CC BY 4.0).

http://creativecommons.org/licenses/by/4.0/

\begin{abstract}
Kaempferia parviflora plants derived from in vitro culture were grown in the glasshouse. A comparison of the yield of total phenolics and total flavonoids under varying extraction conditions from rhizomes harvested from plants of different ages was undertaken. The results showed that phenolic and flavonoid contents in the rhizomes were highest 8 months after planting. Another study found that $2 \mathrm{~g}$ rhizomes extracted in $50 \mathrm{ml}$ of water at $90^{\circ} \mathrm{C}$ for 120 minutes gave the best yield of phenolics and flavonoids. Under these conditions, an average of $210 \mathrm{mg} \mathrm{GAE} / \mathrm{g}$ dry weight of total phenolics and $81 \mu \mathrm{g} \mathrm{QCE} / \mathrm{g}$ dry weight of total flavonoids were obtained.
\end{abstract}

\section{Keywords}

Phenolics, Flavonoids, Kaempferia parviflora, Extraction

\section{Introduction}

Kaempferia parviflora Wall. ex Baker, a member of the Zingiberaceae family, has rhizomes that are dark purple to black in colour. The rhizomes have been traditionally used in Thai folklore medicine for the treatment of leucorrhea, oral diseases [1] [2], stomachache, flatulence, digestive disorders and gastric ulcers [3]. The rhizomes have also been used as a health-promoting agent, and for the treatment of gout, abscesses and colic disorder [4]. A tonic drink made from $K$. 
parviflora rhizomes is commercially available [5]. $K$. parviflora has recently been reported to possess anti-allergic properties [6], anti-peptic ulcer effects [7] and anti-viral protease effects [8]. Recent findings showed that $K$. parviflora rhizome extracts contain numerous flavonoids [9]. Flavonoids are known to increase muscle oxidative capacity and endurance in mice [10]. The rhizomes, which contain flavonoid and exhibit antioxidant effects, enhance oxygen usage and oxidative capacity, resulting in increased performance in aerobic endurance [11]. The major phytoconstituents of Kaempferia parviflora are methoxyflavone derivatives [3], known in Thailand as krachai-dam, that have been used for the treatment of gout, aphthous ulcers, abscesses, allergy and gastrointestinal disorders, as well as an aphrodisiac [12]. Phytochemical studies have revealed that the rhizomes of $K$. parviflora contain phenolic glycosides [13] and many flavonoids such as 5-hydroxy-7-methoxyflavone, 5,7-dimethoxyflavone, and 3,5,7-trimethoxyflavone [14] [15]. Another major active constituent of $K$. parvifloara is 5,7-dimethoxyflavone [15] that is used as a longevity promoting substance and as nerve tonic. The concentrations of phenolic and other secondary metabolites in plants are influenced by many factors, including soil, irrigation, and climatic conditions. Cultivated crops may also show year-to-year variability in the composition of phytochemicals and in total yield [16]. The aim of this study was to investigate the total phenolic and flavonoid compounds that could be extracted from $K$. parvifloara rhizomes of different ages. The extraction process was also investigated for optimal recovery of phenolics and flavonoids following different durations of extraction and at different temperatures.

\section{Materials and Methods}

\subsection{Plant Material}

Plantlets with good root and shoot systems from in vitro cultures of Kaempferia parviflora obtained using the technique described by Zuraida et al. [17] (Figure 1(a)) were washed under running tap water to remove the culture agar. The plantlets were transferred to small ( 3 inch) polybags containing hardening medium and a top soil compost mixture (2:1) (Figure 1(b)) and were maintained at about $70 \%$ relative humidity in the greenhouse. The plantlets were allowed to harden over 30 days, after which they were transferred into large (12 inch) polybags containing a mixture of sand, garden soil and manure in the ratio 1:2:1. Manual irrigation was applied daily. Three plantlets were planted in each polythene bag (Figure 1(b), Figure 1(c)). After 4, 6, 8, 10, and 12 months, the rhizomes of the plants were harvested. A total 30 polybag for each month were harvested, and 150 polybags were used in the entire experiment. The freshly harvested plant materials were stored for further use.

\subsection{Sample Preparation and Extraction Process}

In the standardized procedure, fresh rhizome from plants that had been growing 


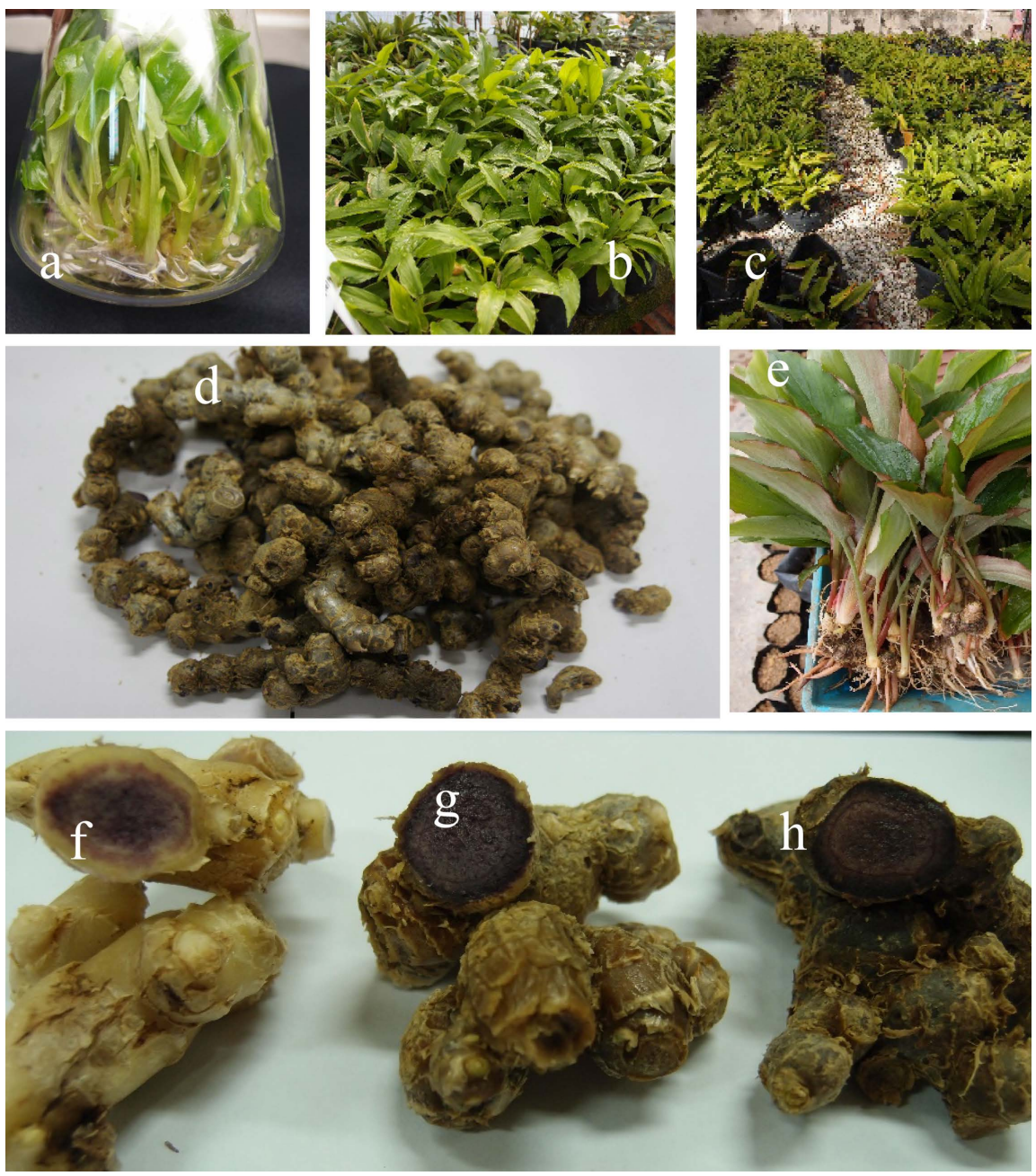

Figure 1. Kaempferia parviflorain vitro planting materials (a), plantlets after one month in the polybag (b), plantlets in the glasshouse (c), 8 month old rhizomes and plants ((d), (e)), cross section of 4 month old rhizomes (f), 8 month old rhizomes (g) and 10 month old rhizomes (h).

for 8 months after transfer to polybags (Figure 1(d) and Figure 1(e)) were harvested and dried immediately in an oven at $50^{\circ} \mathrm{C}$ for 2 days. The rhizomes were homogenized using a blender, packed in plastic bags and kept in dark, dry and cool storage. Distilled water was used for the extraction of flavonoids and phenolics. Extraction was performed at three different temperatures $\left(60^{\circ} \mathrm{C}, 75^{\circ} \mathrm{C}\right.$, and $90^{\circ} \mathrm{C}$ ) for $30,60,90,120,150$, and 180 mins. The rhizome samples were weighed and approx. $2 \mathrm{~g}$ was extracted with $50 \mathrm{~mL}$ distilled water, with the temperature maintained in a shaking water bath. Following filtration through nylon mesh, the extracts were centrifuged for 15 mins and stored at $-18^{\circ} \mathrm{C}$ for analyses that were performed no more than 7 days later.

\subsection{Determination of Phenolic Content}

Total phenolic content (TPC) in the extracts was determined using the Folin-Ciocalteu (FC) method described by McDonald et al. [18]. The extract (100 
$\mu \mathrm{L}$ ) was added to $0.2 \mathrm{~mL}$ FC reagent (5-fold diluted with distilled water) and mixed thoroughly for 3 minutes. Sodium carbonate $(0.2 \mathrm{~mL}, 10 \% \mathrm{w} / \mathrm{v})$ was added to the mixture. Then the mixture was allowed to stand for 30 minutes at room temperature. The absorbance of the mixture was measured at $760 \mathrm{~nm}$ using a UVeVIS spectrophotometer model V-550 (Jasco, Tokyo, Japan). TPC was expressed as milligram gallic acid equivalent per gram dry extract (mg GAE/g dry weight).

\subsection{Determination of Flavonoid Content}

The total flavonoid content (TFC) of the extracts was determined using the aluminium chloride colorimetry method described by Chang et al. [19]. The test sample $(0.1 \mathrm{ml})$ was mixed with $0.1 \mathrm{~mL}$ of $10 \%(\mathrm{w} / \mathrm{v})$ aluminium chloride and $0.1 \mathrm{~mL}$ of $0.1 \mathrm{mM}$ potassium acetate. The mixture was kept at room temperature for 30 minutes and the absorbance of the mixture was measured at $415 \mathrm{~nm}$ using a UVeVIS spectrophotometer. TFC was expressed as microgram quercetin equivalent per gram dry extract ( $\mu \mathrm{g} \mathrm{QCE} / \mathrm{g}$ dry weight).

\subsection{Statistical Analyses}

A completely randomized design was used for the experiment. The results were expressed as means \pm standard deviations. The $\mathrm{t}$-test was used to compare the biochemical results from the different treatments, where a $\mathrm{p}$ value of less than 0.05 was indicative of a significant difference. The Statistical Package for the Social Sciences (SPSS) was used in the statistical analyses.

\section{Results and Discussion}

The efficient extraction of the target active ingredients is an important step in their recovery and purification from plant materials. An extraction process should enable maximum recovery of the active ingredient with its quality maintained [20]. Many techniques have been developed to extract phenolics, such as conventional solvent extraction, microwave-assisted extraction, ultrasound-assisted and supercritical fluid extraction, among which solvent extraction (solid-liquid and liquid-liquid extraction techniques) is the most commonly used and has proven to be a reliable and efficient method [21] [22]. The efficiency of solvent extraction of organic compounds is affected by many factors such as the type of solvent, solvent concentration, time, temperature, $\mathrm{pH}$, number of steps, liquid-to-solid ratio and particle size of the plant material [23].

Phenolic compounds, cyclic derivatives of benzene with one or more hydroxyl groups associated with the aromatic ring, account for one of the largest and most widely distributed group of phytochemicals [24]. They vary considerably in structure, with over 8000 naturally-occurring compounds having been identified [25]. They may exhibit a wide range of physiological and pharmacological properties, such as anti-allergenic, anti-artherogenic, anti-inflammatory, anti-microbial, anti-viral, cardioprotective and vasodilatory effects [26]. Figure 2 


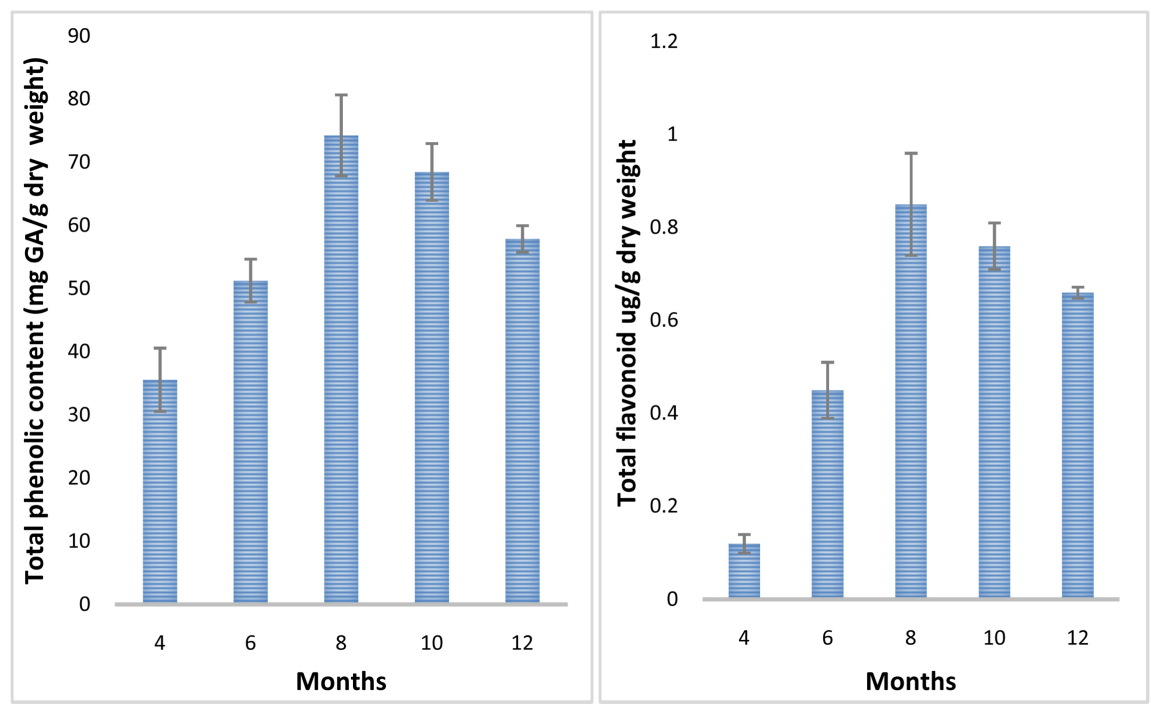

Figure 2. Comparison of total phenolic contents (mg GAE/g dry weight) (a) and flavonoid contents ( $\mu \mathrm{g}$ QCE/g dry weight) (b) in rhizomes of different ages. Values are means \pm SD deviations.

shows the total phenolic and flavonoid contents in the samples harvested from plants of different ages (Figure 1(f), Figure 1(g), Figure 1(h)). The highest phenolic contents (74.3 mg GAE/g dry weight) and flavonoid contents $(0.85 \mu \mathrm{g}$ QCE/g dry weight) were found in rhizomes from plants that had been transferred into polybags for 8 months. After 10 to 12 months, however, the contents of phenolics and flavonoids were found to be reduced to levels ranging from 58 - $69 \mathrm{mg} \mathrm{GAE} / \mathrm{g}$ dry weight and $0.66-0.76 \mu \mathrm{g} \mathrm{QCE} / \mathrm{g}$ dry weight, respectively.

Generally, the efficiency of extraction of phenolic compounds is governed by several variables such as temperature, time and solvent concentration, and composition [27] [28]. The influence of such extraction variables on the recovery of phenolics in $K$. paviflora rhizomes has not been reported. Hence, the present study was aimed at optimizing two critical extraction conditions, viz. temperature and extraction time. The extractable contents of phenolic compounds determined by the Folin-Ciocalteu method for the different variables of temperature and extraction duration are shown in Figure 3(a).

The total phenolic compounds extracted ranged from 45 to $210 \mathrm{mg} \mathrm{GAE} / \mathrm{g}$ dry weight for various time/temperature combinations. Extraction time was an important factor influencing the extraction of phenolic compounds. Figure 3 shows that TPC of the extracts at $90^{\circ} \mathrm{C}$ increased gradually with increasing extraction time from $30 \mathrm{~min}$ ( $45 \mathrm{mg} \mathrm{GAE} / \mathrm{g}$ dry weight) up to $120 \mathrm{~min}(210 \mathrm{mg}$ GAE/g dry weight). Thereafter, there was a decline to $176 \mathrm{mg} \mathrm{GAE} / \mathrm{g}$ dry weight at 180 mins extraction time. This phenomenon could be well explained by the Fick's second law of diffusion that predicts a final equilibrium between the solute concentrations in the solid matrix (plant matrix) and in the bulk solution (solvent) might be reached after a certain time, leading to deceleration in the extraction yield [29]. The increased extraction time of 150 to $180 \mathrm{mins}$ is uneconomical 


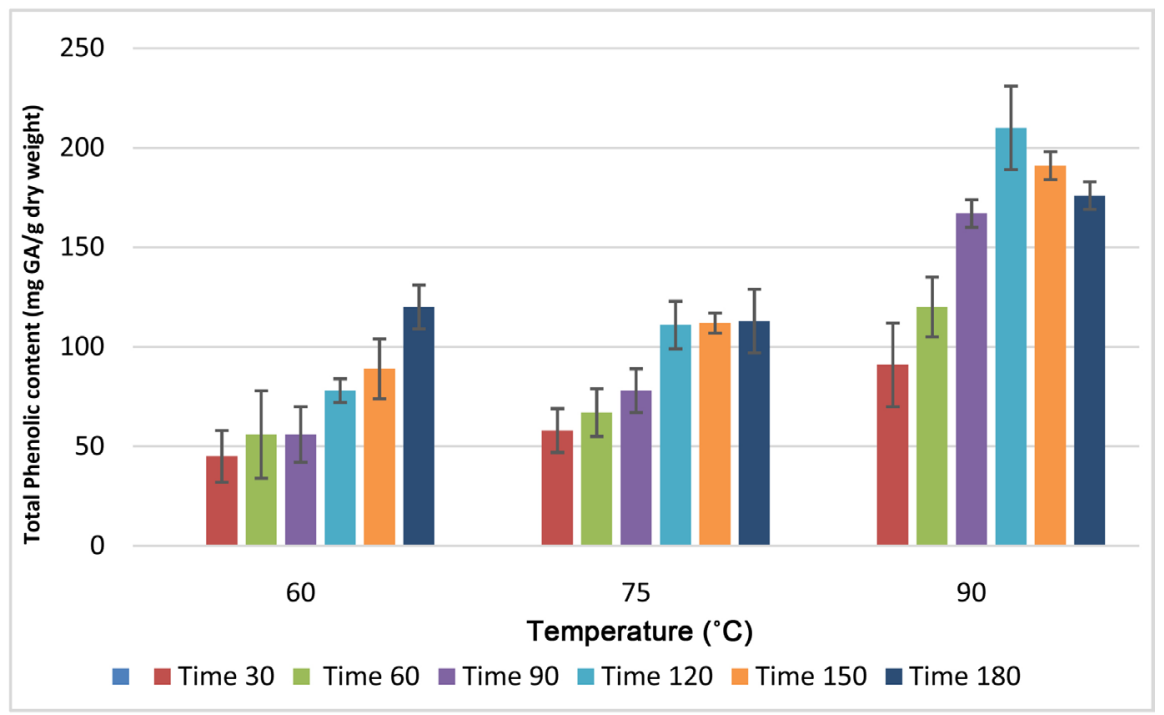

(a)

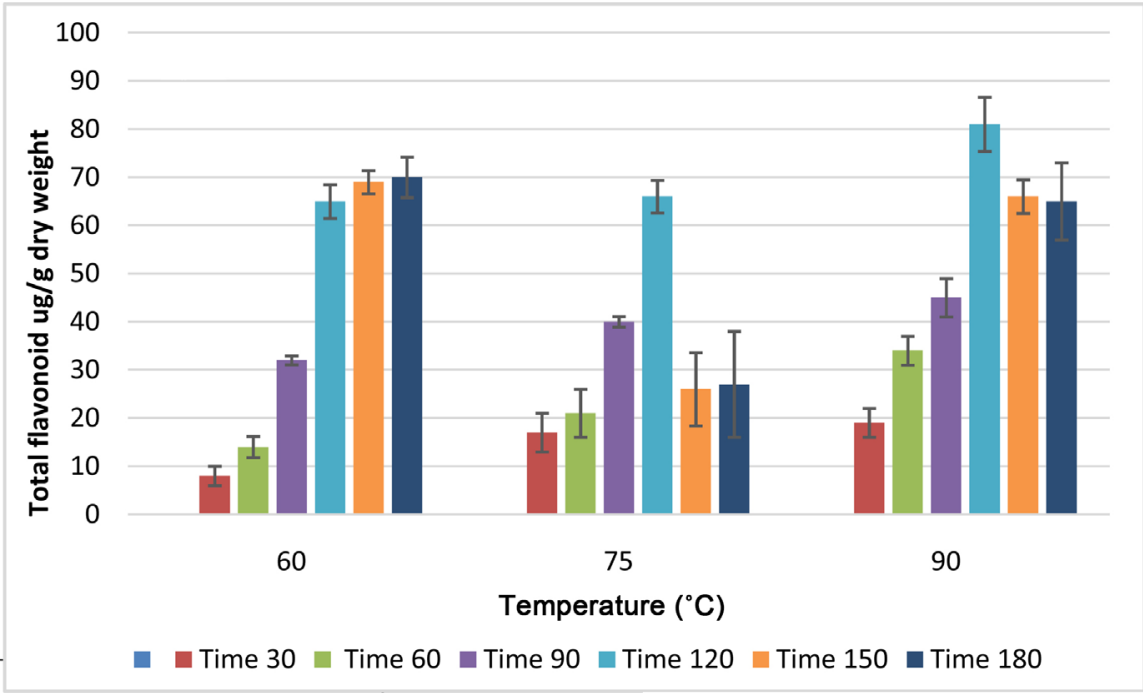

(b)

Figure 3. Influence of extraction time and temperature on extraction efficiency of total phenolic (a) and flavonoid (b) contents from $K$. parviflora rhizomes. Values are means \pm SD deviations.

and time consuming from the industrial point of view. The process could result in a loss of solvent by vaporisation which directly affects the loss of solvent-to-solid ratio of extraction. In our study, the extraction duration of $120 \mathrm{~min}$ was optimal for practical and economic considerations. According to Naczk and Shahidi [30], prolonged extraction time increases the chances of decomposition and oxidation of phenolics due to their long exposure to unfavourable environmental factors as temperature and light. In his study, José [31] noted that maximum yields of hydroxycinnamic acids, flavones, flavonols/flavanones, and total polyphenols were detected at $100^{\circ} \mathrm{C}$ for $5 \mathrm{~min}$ in Thymus vulgaris, whereas higher temperatures and longer exposure times reduced the diversity of extracted polyphenols. 
The effect of temperature and duration of extraction on flavonoid yield is shown in Figure 3(b). As the extraction time at $90^{\circ} \mathrm{C}$ increased from $30 \mathrm{~min}$ to $120 \mathrm{~min}$, the total flavonoid yield rose from $19 \mu \mathrm{g} \mathrm{QCE} / \mathrm{g}$ dry weight to $81 \mu \mathrm{g}$ QCE/g dry weight. At $60^{\circ} \mathrm{C}$, the flavonoid content similarly increased with time of extraction, reaching a maximum yield of $70 \mu \mathrm{g}$ QCE/g dry weight attained with 180 mins extraction duration. Working on Inulahelenium, Chun [32] reported that increasing the temperature from $30^{\circ} \mathrm{C}$ to $60^{\circ} \mathrm{C}$ improved the total flavonoid yield from 13.79 to $18.08 \mathrm{mg} / \mathrm{g}$. Extraction efficiency decreased slightly when the extraction temperature exceeded $60^{\circ} \mathrm{C}$, and this temperature was thus considered appropriate for peak total flavonoid yield.

In a study carried out by Liu et al. [33], with a fixed water-to-raw-material ratio of $50 \mathrm{ml} / \mathrm{g}$ and an extraction time of 60 minutes, the extraction efficiency of flavonoids increased gradually with extraction temperature. They note, nevertheless, that since flavonoids are heat-sensitive, excessive temperatures would cause degradation. Low temperature extraction saves energy, and $80^{\circ} \mathrm{C}$ was selected as the optimal extraction temperature for flavonoid extraction in Coreopsis tinctoria Nutt.

At high temperatures, the flavonoid and phenolic content can be increased as a result of enhancement of their solubility, extraction rate, diffusion rate, and the reduced surface tension and solvent viscosity [34]. Ghasemzadeh and Hawa [35], who worked with Pandanus amaryllifolius Roxb., found that flavonoid content increased with increasing extraction temperatures until $70^{\circ} \mathrm{C}$. Hence, extraction temperatures below $80^{\circ} \mathrm{C}$ were appropriate to minimize the possibility of degradation of the flavonoid and phenolic compounds, which had been observed to occur with the application of high temperatures [36] [37]. Previous studies have shown that the application of very high temperatures $\left(\geq 95^{\circ} \mathrm{C}\right)$ may also alter the concentration and composition of phenolic compounds [38]. Although some researchers hold the view that the critical temperature for flavonoid extraction is below $80^{\circ} \mathrm{C}$ [39], this threshold temperature would be variable in different plants and plant organs, with PAL or CHS enzymes activity mediating the effects [40].

\section{Conclusion}

Optimal conditions were established to extract total phenolic and flavonoids from the rhizomes of $K$. parviflora. Rhizomes from eight-month old plants (from the time of transfer to the polybag) gave the highest yield of both phenolics and flavonoids. Optimal water extraction of these two classes of compounds was achieved at $90^{\circ} \mathrm{C}$ for an extraction duration of 120 mins.

\section{References}

[1] Chomchalow, N., Bansiddh, I.J. and MacBaine, C. (2003) Amazing Thai Medicinal Plants. Horticultural Research Institute (HRI). Department of Agriculture and Horticultural Science Society of Thailand (HSST), Bangkok.

[2] Sudwan, P., Saenphet, K., Saenphet, S. and Suwansirikul, S. (2006) Effect of Kaempferia parviflora Wall Ex. Baker on Sexual Activity of Male Rats and Its Toxicity. 
Southeast Asian Journal of Tropical Medicine Public Health, 37, 210-215.

[3] Wattanapitayakul, S.K., Suwatronnakorn, M., Chularojmontri, L., Herunsalee, A., Niumsakul, S., Charuchongkolwongse, S., et al. (2007) Kaempferia parviflora Ethanolic Extract Promoted Nitric Oxid Production in Human Umbilical Vein Endothelial Cells. Journal of Ethnopharmacology, 110, 559-562.

https://doi.org/10.1016/j.jep.2006.09.037

[4] Yenjai, C., Sutthanut, K., Sripanidkulchai, B., Mungkhun, N., Wongma, C., Mukdasai, S., et al. (2007) Further Studies of Bioactive Flavonoids from Kaempferia parviflora. KKU Science Journal, 35, 37-41.

[5] Yenjai, C., Prasanphen, K., Daodee, S., Wongpanich, V. and Kittakoop, P. (2004) Bioactive Flavonoids from Kaempferia parviflora. Fitoterapia, 75, 89-92. https://doi.org/10.1016/j.fitote.2003.08.017

[6] Tewtrakul, S., Subhadhirasakul, S. and Kummee, S. (2008) Anti-Allergic Activity of Compounds from Kaempferia parviflora. Journal of Ethnopharmacology, 116, 191-193. https://doi.org/10.1016/j.jep.2007.10.042

[7] Rujjanawate, C., Kanjanapothi, D., Amornlerdpison, D. and Pojanagaroon, S. (2005) Antigastric Ulcer Effect of Kaempferia parviflora. Journal of Ethnopharmacology, 102, 120-122. https://doi.org/10.1016/j.jep.2005.03.035

[8] Sookkongwaree, K., Geitmann, M., Roengsumran, S., Petsom, A. and Danielson, U.H. (2006) Inhibition of Viral Proteases by Zingiberaceae Extracts and FlavonoidsIsolated from Kaempferia parviflora. Pharmazie, 61, 717-721.

[9] Sutthanut, K., Sripanidkulchai, B., Yenjai, C. and Jay, M. (2007) Simultaneous Identification and Quantitation of 11 Flavonoid Constituents in Kaempferia parviflora by Gas Chromatography. Journal of Chromatography A, 1143, 227-233.

[10] Davis, J.M., Murphy, E.A., Carmichael, M.D. and Davis, B. (2009) Quercetin Increases Brain and Muscle Mitochondrial Biogenesis and Exercise Tolerance. American Journal of Physiology, Regulatory Integrative and Comparative Physiology, 296, R1071-R1077. https://doi.org/10.1152/ajpregu.90925.2008

[11] Wattanathorn, J., Muchimapura, S., Tong-Un, T., Saenghong, N., Thukhum-Mee, W. and Sripandidkulchai, B. (2012) Positive Modulation Effect of 8-Week Consumption of Kaempferia parviflora on Health-Related Physical Fitness and Oxidative Status in Healthy Elderly Volunteers. Evidence-Based Complementary and Alternative Medicine, 2012, Article ID: 732816.

[12] Pengcharoen, O. (2002) Technology Chao Barn. Matichon Press, Bangkok, 42-43.

[13] Azuma, T., Tanaka, Y. and Kikuzaki, H. (2008) Phenolic Glycosides from Kaempferia parviflora. Phytochemistry, 69, e2743-e2748.

[14] Yenjai, C., Prasanphen, K., Daodee, S., Wongpanich, V. and Kittakoop, P. (2004) Bioactive Flavonoids from Kaempferia parviflora. Fitoterapia, 75, 89-92. https://doi.org/10.1016/j.fitote.2003.08.017

[15] Patanasethanont, D., Nagai, J., Yumoto, R., et al. (2007) Effects of Kaempferia parviflora Extracts and Their Flavone Constituents on P-Glycoprotein Function. Journal of Pharmaceutical Sciences, 96, e223-e233.

[16] Bourgaud, F., Gravot, A., Milesi, S. and Gontier, E. (2001) Production of Plant Secondary Metabolites: A Historical Perspective. Plant Science, 161, 839-851. https://doi.org/10.1016/S0168-9452(01)00490-3

[17] Zuraida, A.R., Erny Sabrina, M.N., MohdShukri, M.A., Razali, M., Norma, H., Wan Zaliha, W.S. and AyuNazreena, O. (2015) In Vitro Micropropagation of a Valuable Medicinal Plant, Piper crocatum. International Journal of Pure \& Applied Bios- 
cience, 3, 10-16.

[18] McDonald, S., Prenzler, P.D., Autolovich, M. and Robards, K. (2001) Phenolic Content and Antioxidant Activity of Olive Extracts. Food Chemistry, 73, 73-84. https://doi.org/10.1016/S0308-8146(00)00288-0

[19] Chang, C., Yang, M., Wen, H. and Chern, J. (2002) Estimation of Total Flavonoid Content in Propolis by Two Complementary Colorimetric Methods. Journal of Food and Drug Analysis, 10, 178-182.

[20] Spigno, G., Tramelli, L. and De Faveri, D.M. (2007) Effects of Extraction Time, Temperature and Solvent on Concentration and Antioxidant Activity of Grape Marc Phenolics. Journal of Food Engineering, 81, 200-208.

https://doi.org/10.1016/j.jfoodeng.2006.10.021

[21] Chirinos, R., Rogez, H., Campos, D., Pedreschi, R. and Larondelle, Y. (2007) Optimization of Extraction Conditions of Antioxidant Phenolic Compounds from Mashua (Tropaeolum tuberosum Ruíz\&Pavón) Tubers. Separation and Purification Technology, 55, 217-225. https://doi.org/10.1016/j.seppur.2006.12.005

[22] Banik, R.M. and Pandey, D.K. (2008) Optimizing Conditions for Oleanolic Acid Extraction from Lantana Camara Roots using Response Surface Methodology. Industrial Crops and Products, 27, 241-248.

[23] Cacace, J.E. and Mazza, G. (2003) Optimization of Extraction of Anthocyanins from Black Currants with Aqueous Ethanol. Journal of Food Science, 68, 209-215. https://doi.org/10.1111/j.1365-2621.2003.tb14146.x

[24] Andjelkovic, M., Camp, J.V., Meulenaer, B.D., Depaemelaere, G., Socaciu, C., Verloo, M. and Verhe, R. (2006) Iron-Chelation Properties of Phenolic Acids Bearing Catechol and Galloyl Groups. Food Chemistry, 98, 23-31. https://doi.org/10.1016/j.foodchem.2005.05.044

[25] Balasundram, N., Ai, T.Y., Sambanthamurthi, R., Sundram, K. and Samman, S. (2005) Antioxidant Properties of Palm Fruit Extracts. Asia Pacific Journal of Clinical Nutrition, 4, 319-324.

[26] Tabart, J., Kevers, C., Sipel, A., Pincemail, J., Defraigne, J.O. and Dommes, J. (2007) Optimisation of Extraction of Phenolics and Antioxidants from Black Currant Leaves and Buds and of Stability during Storage. Food Chemistry, 105, 1268-1275. https://doi.org/10.1016/j.foodchem.2007.03.005

[27] Saha, J., Biswas, A., Chhetri, A. and Sarkar, P.K. (2011) Response Surface Optimization of Antioxidant Extraction from Kinema, A Bacillus Fermented Soybean Food. Food Chemistry, 129, 507-513. https://doi.org/10.1016/j.foodchem.2011.04.108

[28] A Lothman, M., Bhat, R. and Karim, A.A. (2009) UV Radiation-Induced Changes of Antioxidant Capacity of Fresh-Cut Tropical Fruits. Innovative Food Science and Emerging Technologies, 10, 512-516.

[29] Silva, E.M., Souza, J.N.S., Rogez, H., Rees, J.F. and Larondelle, Y. (2007) Antioxidant Activities and Polyphenolic Contents of Fifteen Selected Plant Species from the Amazonian Region. Food Chemistry, 101, 1012-1018. https://doi.org/10.1016/j.foodchem.2006.02.055

[30] Naczk, M. and Shahidi, F. (2004) Extraction and Analysis of Phenolics in Food. Journal of Chromatography $A, 1054,95-111$. https://doi.org/10.1016/S0021-9673(04)01409-8

[31] Vergara-Salinas, J., Pérez-Jiménez, J., Torres, J., Agosin, E. and Pérez-Correa, J.R. (2012) Effects of Temperature and Time on Polyphenolic Content and Antioxidant Activity in The Pressurized Hot Water Extraction of Deodorized Thyme (Thymus vulgaris). Journal of Agricultural and Food Chemistry, 60, 10920-10929. 
https://doi.org/10.1021/jf3027759

[32] Guo, C.-Y., Wang, J., Hou, Y., Zhao, Y.-M., Shen, L.X. and Zhang, D.-S. (2013) Orthogonal Test Design for Optimizing the Extraction of Total Flavonoids from Inulahelenium. Pharmacognosy Magazine, 9, 192-195.

https://doi.org/10.4103/0973-1296.113260

[33] Liu, X.F., Liu, L., Wang, Y.G., Leng, F.F., Wang, S.W. and Li, Y.C. (2014) Optimization of Total Flavonoids Extraction from Coreopsis tinctoria Nutt. by Response Surface Methodology, Kemija u industriji: Časopis kemičara i kemijskih inženjera Hrvatske, Vol. 63, 391-396.

[34] Ju, Z.Y. and Howard, L.R. (2003) Effects of Solvent and Temperature on Pressurized Liquid Extraction of Anthocyanins and Total Phenolics from Dried Red Grape Skin. Journal of Agricultural and Food Chemistry, 51, 5207-5213.

https://doi.org/10.1021/jf0302106

[35] Ghasemzadeh, A. and Hawa, Z.E. (2014) Optimization of Reflux Conditions for Total Flavonoid and Total Phenolic Extraction and Enhanced Antioxidant Capacity in Pandan (Pandanus Amaryllifolius Roxb.) using Response Surface Methodology. The Scientific World Journal, 2014, Article ID: 523120.

[36] Nuutila, A.M., Kammiovirta, K. and Oksman-Caldentey, K.-M. (2002) Comparison of Methods for the Hydrolysis of Flavonoids and Phenolic Acids from Onion and Spinach for HPLC Analysis. Food Chemistry, 76, 519-525. https://doi.org/10.1016/S0308-8146(01)00305-3

[37] Sensoy, I., Rosen, R.T., Ho, C.-T. and Karwe, M.V. (2006) Effect of Processing on Buckwheat Phenolics and Antioxidant Activity. Food Chemistry, 99, 388-393. https://doi.org/10.1016/j.foodchem.2005.08.007

[38] Igual, M., GarcIa-MartInez, E., Camacho, M.M. and MartInez-Navarrete, N. (2010) Effect of Thermal Treatment and Storage on the Stability of Organic Acids and the Functional Value of Grapefruit Juice. Food Chemistry, 118, 291-299. https://doi.org/10.1016/j.foodchem.2009.04.118

[39] Xu, G., Ye, X., Chen, J. and Liu, D. (2007) Effect of Heat Treatment on the Phenolic Compounds and Antioxidant Capacity of Citrus Peel Extract. Journal of Agricultural and Food Chemistry, 55, 330-335. https://doi.org/10.1021/jf0625171

[40] Lafuente, M.T., Ballester, A.R., Calejero, J. and Gonzalez-Candelas, L. (2011) Effect of High-Temperature-Conditioning Treatments on Quality, Flavonoid Composition and Vitamin C of Cold Stored "Fortune" Mandarins. Food Chemistry, 128, 1080-1086. https://doi.org/10.1016/j.foodchem.2011.03.129 